\title{
Salts of Amoxapine with Improved Solubility for Enhanced Pharmaceutical Applicability
}

\author{
Mayank Joshi and Angshuman Roy Choudhury*(1)
}

Department of Chemical Sciences, Indian Institute of Science Education and Research (IISER) Mohali, Sector 81, Knowledge City, S.A.S. Nagar, Manauli PO, Mohali 140306, Punjab, India

\section{Supporting Information}

ABSTRACT: The objective of pharmaceutical cocrystallization is to create crystalline analogues that have vastly different properties, such as solubility, melting point, stability, and bioavailability from that observed in the pure active pharmaceutical ingredients (APIs). Amoxapine is a benzoxazepine derivative and exhibits antidepressant properties. Amoxapine has very low solubility in water, so it was cocrystallized with natural acids in a 1:1 ratio in appropriate solvents by the solvent-drop grinding method. Single crystals of cocrystals were grown by the solvent evaporation method in water, ethanol, and methanol. Crystal structures of API salts were determined by single-crystal X-ray diffraction. Salts were characterized by Fourier transform infrared spectroscopy, differential scanning calorimetry, and powder X-ray diffraction. Solubility of salts was determined in water by the shake-flask method at $37{ }^{\circ} \mathrm{C}$ using UV-vis spectroscopy. Salts of amoxapine with different acids were successfully developed, and their crystal structure was determined. Enhanced solubility was found in the salts of amoxapine for pharmaceutical application in drug formulation.

\section{INTRODUCTION}

The concept of crystal engineering ${ }^{1}$ has emerged since 1989 as an immense tool in designing novel crystalline phases of various combinations of different materials to control and manipulate physical and chemical properties of already existing materials. The application of crystal engineering ranges from designing multicomponent crystalline phases of a combination of two or more compounds ${ }^{2}$ to the formation of large metal-organic frameworks ${ }^{3}$ and covalent organic frameworks. ${ }^{4}$ The idea of formation of different crystalline phases of various biologically important molecules to enhance their physical properties has led the researchers across the globe to a new area of cocrystallization of drugs with other biologically acceptable molecules. $^{5-8}$ Cocrystallization and salt formation of various pharmaceutically important molecules have emerged as an expanding field for contemporary research., ${ }^{9,10}$ The FDA proposed that the cocrystals are "solids that are crystalline materials composed of two or more molecules in the same crystal lattice”. According to a latest definition, ${ }^{10}$ a group of authors considered the classification of ionic species as cocrystals. Cocrystallization of antibacterial agents, ${ }^{10}$ antifungal drugs, ${ }^{11}$ various antidepressants, ${ }^{12}$ antitubercular agents, ${ }^{13}$ and various others types of drugs ${ }^{14,15}$ have been reported to have led to better solubility, dissolution rate, thermal and environmental stability, and bioavailability. Our recent efforts on cocrystallization of fluconazole resulted into the generation of new polymorphs of fluconazole under the influence of different

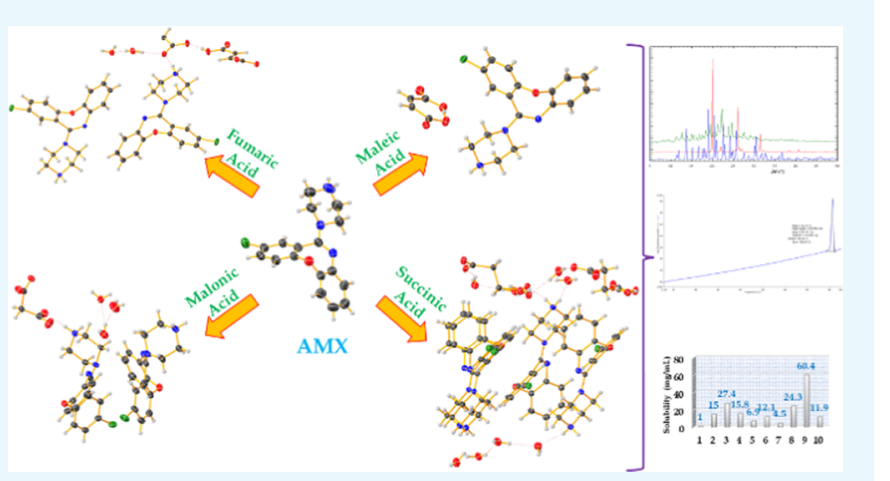

coformers. ${ }^{16}$ This study indicated that the crystal engineering approach may apparently fail to generate the targeted cocrystal but eventually result into a new crystalline phase (polymorph) of the native drug. Our experiments of cocrystallization of enrofloxacin resulted into seven novel cocrystals of it with significantly improved solubility and thermal stability. ${ }^{17}$ In this manuscript, we intend to demonstrate the scope of cocrystallization of a tricyclic dibenzoxazepine-based antidepressant, amoxapine (AMX; 2-chloro-11-(piperazin-1-yl)dibenzo $[b, f][1,4]$ oxazepine), which is widely used for the treatment of depression. ${ }^{18}$

Amoxapine became popular in the United States in 1980 as a rapidly acting antidepressant compared with other cyclic antidepressants available in the market at that period of time. ${ }^{19}$ The $\mathrm{N}$-desmethyl analogue of loxapine, named as amoxapine $^{20}$ (Figure 1), had shown neuroleptic action in addition to antidepressant activity, ${ }^{21}$ specially in psychotic depression. $^{22}$ Various activities of AMX, like noradrenaline reuptake inhibition, ${ }^{23}$ 5-HT2 receptor antagonism, ${ }^{24}$ and dopamine D2 receptor antagonism, ${ }^{25}$ have been studied. AMX blocks the reuptake of the neurotransmitter norepinephrine, with little effect on serotonin. ${ }^{26}$ AMX may be an

Received: December 19, 2017

Accepted: February 9, 2018

Published: February 27, 2018 
<smiles>Clc1ccc2c(c1)C(N1CCNCC1)=Nc1ccccc1O2</smiles>

Figure 1. Structure of amoxapine drug molecule.

atypical antipsychotic agent because it antagonizes dopamine D2 receptor. ${ }^{27}$

AMX has poor water solubility and lower bioavailability. ${ }^{28}$ These physical problems of AMX can be solved by cocrystallization of AMX with organic acids, which are generally recognized as safe (GRAS) in the list of The Food Safety and Inspection Service regulations. ${ }^{29}$ We have selected D-(-)-tartaric acid, fumaric acid, D-(+)-tartaric acid, maleic acid, succinic acid, citric acid, malonic acid, L-malic acid, and adipic acid for our experiments.

\section{RESULTS AND DISCUSSION}

Amoxapine $\left(\mathrm{p} K_{\mathrm{a}}=8.83\right)$ is likely to form salts with GRAS organic acids having $\mathrm{p} K_{\mathrm{a}}$ ranging from 2 to 5 , which are not so strong to cause harm to AMX and the cells. According to the $\Delta \mathrm{p} K_{\mathrm{a}}$ rule of $3,^{30-32}$ salt formation occurs at at least three units $\mathrm{pK}_{\mathrm{a}}^{32}$ difference, whereas $\Delta \mathrm{p} K_{\mathrm{a}}$ of $<1$ means it forms a neutral cocrystal. $\Delta \mathrm{p} K_{\mathrm{a}}$ in the range $1-3$ means this is a gray zone of intermediate proton states. This concept is also observed in the case of AMX (Table 1). Conspicuously, salt formation is detected in the case of all acids that are used as coformers. $\mathrm{p} K_{\mathrm{a}}$ calculations were carried out by a ChemAxon calculator. ${ }^{33}$

Table 1. $\mathrm{p} K_{\mathrm{a}}$ and $\Delta \mathrm{p} K_{\mathrm{a}}$ Values of AMX and Coformers Used in This Study

\begin{tabular}{|c|c|c|c|c|}
\hline $\begin{array}{l}\text { SI. } \\
\text { no. }\end{array}$ & name & $\mathrm{p} K_{\mathrm{a}}$ & $\Delta \mathrm{p} K_{\mathrm{a}}$ & $\begin{array}{c}\text { ratio of AMX and } \\
\text { acid }\end{array}$ \\
\hline 1 & amoxapine & 8.83 & & \\
\hline 2 & $\mathrm{D}-(-)$-tartaric acid & 2.72 & 6.11 & $1: 1$ \\
\hline 3 & fumaric acid & 3.03 & 5.80 & $1: 1$ \\
\hline 4 & $\mathrm{D}-(+)$-tartaric acid & 2.72 & 6.11 & $1: 1$ \\
\hline 5 & maleic acid & 3.05 & 5.78 & $1: 1$ \\
\hline 6 & succinic acid & 3.55 & 5.28 & $1: 1$ \\
\hline 7 & citric acid & 3.05 & 5.78 & $1: 1$ \\
\hline 8 & malonic acid & 2.85 & 5.98 & $1: 1$ \\
\hline 9 & L-malic acid & 3.20 & 5.63 & $1: 1$ \\
\hline 10 & adipic acid & $4.43,5.41$ & $4.4,3.42$ & $1: 1$ \\
\hline
\end{tabular}

Crystal Structure Description. We have produced nine novel cocrystals of AMX and characterized them by powder Xray diffraction (PXRD). Single crystals, suitable for structure determination, could be grown only for four cocrystals. Single crystals of these four salts were grown by a slow evaporation method at $4{ }^{\circ} \mathrm{C}$ by using different solvent systems (AMXfumaric acid crystal in water-methanol mixture; AMX-maleic acid crystal in water-ethanol mixture; AMX-succinic acid and AMX-malonic acid single crystals in an aqueous solution). Crystallographic data and hydrogen bonds are listed in Tables 2 and 3 for salts of AMX with fumaric acid, maleic acid, succinic acid, and malonic acid.

AMX/Fumaric Acid Salt (1:1). The asymmetric unit of the structure (triclinic system, $P \overline{1}$ space group) contained two molecules of $\mathrm{AMX}^{+}$cation, one monofumarate anion and a half molecule of fumarate anion, and two molecules of water (Figure $2 \mathrm{a}$ ). $\mathrm{AMX}^{+}$is connected to fumarate anion by N6$\mathrm{H} 6 \mathrm{~A} \cdots \mathrm{O} 7$ hydrogen bond and with water molecule via N6$\mathrm{H} 6 \mathrm{~B} \cdots \mathrm{O} 10$ hydrogen bond (Figure $2 \mathrm{a}$ ). The carboxylate anions are also hydrogen-bonded to each other $(\mathrm{O} 4-\mathrm{H} 4 \cdots \mathrm{O} 8)$, and the water molecules are hydrogen-bonded to the carboxylate anions $(\mathrm{O} 7 \cdots \mathrm{H} 10 \mathrm{~B}-\mathrm{O} 10)$ (Figure 2a) as well. Water molecules are also hydrogen-bonded among them (O10$\mathrm{H} 10 \mathrm{~A}$...O9). Two $\mathrm{AMX}^{+}$ions are arranged antiparallel in the lattice and are connected to each other by weak $\mathrm{C}-\mathrm{H} \cdots \mathrm{Cl}$ hydrogen bond and $\mathrm{C}-\mathrm{H} \cdots \pi$ interactions (Figure 2b). Alternate layers of acid-water channel and drug molecules are found in the crystal packing (Figure 2c), where the hydrogen bonds are responsible for the interlayer connectivity. Acid and water molecules are bonded by strong hydrogen bonds, whereas $\mathrm{AMX}^{+}$ions are attached by weak interactions $(\mathrm{C}-\mathrm{H} \cdots \mathrm{Cl}$ and $\mathrm{C}-\mathrm{H} \cdots \pi)$ in the same layer.

AMX/Maleic Acid Salt (1:1). One molecule of each of $\mathrm{AMX}^{+}$ cation and maleic acid anion are present in the asymmetric unit (monoclinic, space group $P 2_{1} / c$ ) (Figure $3 a$ ). $\mathrm{AMX}^{+}$and maleic acid are linked via $\mathrm{N} 3-\mathrm{H} 3 \mathrm{~A} \cdots \mathrm{O} 3$ and $\mathrm{N} 3-\mathrm{H} 3 \mathrm{~B} \cdots \mathrm{O} 4$ hydrogen bonds (Figure 3a). Intramolecular hydrogen bond is also

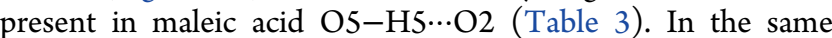
layer of $\mathrm{AMX}^{+}$, cations are arranged parallel to $b$ axis but alternately rotated by $180{ }^{\circ} \mathrm{C}$, as shown in the Figure $3 \mathrm{~b}$, whereas the cations are connected by weak $\mathrm{C}-\mathrm{H} \cdots \mathrm{Cl}$ (Figure $3 c$ ) hydrogen bonds along $c$ axis. Interlayer interaction of $\mathrm{AMX}^{+}$(Figure 3c) occurs by $\mathrm{C}-\mathrm{H} \cdots \pi$ and $\pi$ stacking interactions. In this crystal packing, $\mathrm{AMX}^{+}$cations are organized in parallel so the piperazine ring is present in the same side. They formed two layers of $\mathrm{AMX}^{+}$, attached by one layer of maleic acid (Figure 3c).

AMX/Succinic Acid Salt (1:1). The asymmetric unit of this crystal has 4 molecules of $\mathrm{AMX}^{+}$cation, 2 molecules of disuccinate anion, and 10 molecules of water (monoclinic, $P 2_{1}$ / $c$ space group) (Figure $4 \mathrm{a}) . \mathrm{AMX}^{+}$and succinate anions are connected via strong hydrogen bonds (N3-H3A...O5, N6-

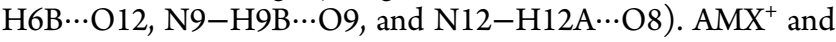
water molecules are interlinked by $\mathrm{N} 3-\mathrm{H} 3 \mathrm{~B} \cdots \mathrm{O} 13$, N6-

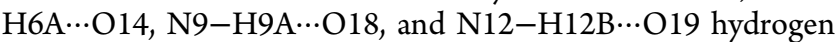
bonds (Table 3). Two $\mathrm{AMX}^{+}$molecules are arranged antiparallel in a layer, and they are interconnected by $\mathrm{C}-$ $\mathrm{H} \cdots \pi, \mathrm{C}-\mathrm{H} \cdots \mathrm{Cl}$, and $\mathrm{C}-\mathrm{H} \cdots \mathrm{O}$ interactions (Figure $4 \mathrm{~b}$ ). Layers of $\mathrm{AMX}^{+}$and succinic acid-water channel are arranged in an alternate manner in crystal packing because active pharmaceutical ingredient (API) is arranged antiparallel in the same layer (Figure 4c).

AMX/Malonic Acid Salt (1:1). The asymmetric unit is shown, containing two molecules of $\mathrm{AMX}^{+}$cation, one molecule of malonate anion, and three molecules of water (monoclinic, $P 2_{1} / c$ ) (Figure $5 \mathrm{a}$ ). $\mathrm{AMX}^{+}$cations are attached to malonate anions by strong hydrogen bonding (Table 3 ) of N3-H3A $\cdots \mathrm{O} 4, \mathrm{~N} 3-\mathrm{H} 3 \mathrm{~A} \cdots \mathrm{O} 6, \mathrm{~N} 3-\mathrm{H} 3 \mathrm{~B} \cdots \mathrm{O} 3, \mathrm{~N} 6-\mathrm{H} 6 \mathrm{~A} \cdots$ $\mathrm{O} 5, \mathrm{~N} 6-\mathrm{H} 6 \mathrm{~A} \cdots \mathrm{O} 6, \mathrm{~N} 6-\mathrm{H} 6 \mathrm{~B} \cdots \mathrm{O} 3$, and $\mathrm{N} 6-\mathrm{H} 6 \mathrm{~B} \cdots \mathrm{O} 4$. Water molecules are also interconnected by hydrogen bonds (Table 3 ). $\mathrm{AMX}^{+}$cations are arranged in a partially parallel pattern in the same layer and connected by $\mathrm{C}-\mathrm{H} \cdots \pi$ and $\mathrm{C}-$ $\mathrm{H} \cdots \mathrm{O}$ (Figure $5 \mathrm{~b}$ ), forming a chain of molecules. Two layers of 
Table 2. Crystallographic Data of AMX Salts

\begin{tabular}{|c|c|c|c|c|}
\hline parameter & AMX/fumaric acid & AMX/maleic acid & AMX/succinic acid & AMX/malonic acid \\
\hline empirical formula & $\begin{array}{l}2\left(\mathrm{C}_{17} \mathrm{H}_{17} \mathrm{ClN}_{3} \mathrm{O}\right)^{+},\left(\mathrm{C}_{4} \mathrm{H}_{3} \mathrm{O}_{4}\right)^{-}, \\
\quad\left(\mathrm{C}_{2} \mathrm{HO}_{2}\right)^{-}, 2\left(\mathrm{H}_{2} \mathrm{O}\right)\end{array}$ & $\left(\mathrm{C}_{17} \mathrm{H}_{17} \mathrm{ClN}_{3} \mathrm{O}\right)^{+},\left(\mathrm{C}_{4} \mathrm{H}_{3} \mathrm{O}_{4}\right)^{-}$ & $\begin{array}{l}2\left(\mathrm{C}_{17} \mathrm{H}_{17} \mathrm{ClN}_{3} \mathrm{O}\right)^{+} \\
\quad\left(\mathrm{C}_{4} \mathrm{H}_{4} \mathrm{O}_{4}\right)^{2-}, 5\left(\mathrm{H}_{2} \mathrm{O}\right)\end{array}$ & $\begin{array}{l}2\left(\mathrm{C}_{17} \mathrm{H}_{17} \mathrm{ClN}_{3} \mathrm{O}\right)^{+} \\
\quad\left(\mathrm{C}_{3} \mathrm{H}_{2} \mathrm{O}_{4}\right)^{2-}, 2\left(\mathrm{H}_{2} \mathrm{O}\right)\end{array}$ \\
\hline CCDC number & 1590199 & 1590200 & 1590201 & 1812331 \\
\hline formula weight & 429.85 & 429.85 & 835.72 & 767.65 \\
\hline crystal system & triclinic & monoclinic & monoclinic & monoclinic \\
\hline space group & $P \overline{1}$ & $P 2_{1} / c$ & $P 2_{1} / c$ & $P 2_{1} / c$ \\
\hline$a(\AA)$ & $9.2238(2)$ & $20.5724(6)$ & $15.7210(2)$ & $21.3450(7)$ \\
\hline$b(\AA)$ & $12.4815(2)$ & $9.8586(3)$ & $19.4546(3)$ & $9.9547(3)$ \\
\hline$c(\AA)$ & $17.0725(3)$ & $9.7866(3)$ & $25.7568(4)$ & $17.4738(6)$ \\
\hline$\alpha(\operatorname{deg})$ & $86.2850(10)$ & 90 & 90 & 90 \\
\hline$\beta(\operatorname{deg})$ & $89.375(2)$ & $97.143(3)$ & $97.940(2)$ & $102.057(3)$ \\
\hline$\gamma(\operatorname{deg})$ & $82.224(2)$ & 90 & 90 & 90 \\
\hline$V\left(\AA^{3}\right)$ & $1943.33(6)$ & $1969.46(10)$ & $7802.1(2)$ & $3631.0(2)$ \\
\hline$Z$ & 4 & 4 & 8 & 4 \\
\hline$\rho_{\text {calc }}\left(\mathrm{g} / \mathrm{cm}^{-3}\right)$ & 1.469 & 1.450 & 1.423 & 1.404 \\
\hline temperature $(\mathrm{K})$ & $100.0(2)$ & $100.0(2)$ & $100.0(2)$ & $100.0(2)$ \\
\hline$\mu / \mathrm{mm}^{-1}$ & 0.237 & 0.234 & 0.236 & 0.241 \\
\hline $2 \theta_{\min , \max }(\mathrm{deg})$ & $5.062,65.696$ & $5.746,65.678$ & $5.078,65.546$ & $4.928,65.604$ \\
\hline$F(000)$ & 896.0 & 896.0 & 3520.0 & 1608.0 \\
\hline$h_{\min , \max } ; k_{\min , \max } ; l_{\min , \max }$ & $-14,14 ;-18,17 ;-25,25$ & $-30,31 ;-14,14 ;-14,14$ & $-23,23 ;-28,29 ;-38,38$ & $-32,31 ;-14,14 ;-26,26$ \\
\hline total no. of reflections & 43941 & 43349 & 183373 & 67443 \\
\hline$R_{\text {int }}$ & 0.0249 & 0.0525 & 0.0528 & 0.0546 \\
\hline no. of unique reflections & 13758 & 7218 & 28243 & 12968 \\
\hline$R_{1}[I>2 \sigma(I)]$ & 0.0419 & 0.0677 & 0.0699 & 0.0695 \\
\hline $\mathrm{w} R_{2}$ (all data) & 0.1190 & 0.1989 & 0.2243 & 0.2009 \\
\hline GooF on $F^{2}$ & 1.063 & 1.076 & 1.037 & 1.035 \\
\hline$\Delta \rho_{\max , \min } / \mathrm{e} \AA^{-3}$ & $0.61,-0.29$ & $0.50,-0.37$ & $1.19,-0.60$ & $1.19,-0.51$ \\
\hline
\end{tabular}

$\mathrm{AMX}^{+}$are also connected by a different $\mathrm{C}-\mathrm{H} \cdots \pi$ interaction (Figure 5c). Two layers of $\mathrm{AMX}^{+}$in the lattice are connected by $\mathrm{C}-\mathrm{H} \cdots \mathrm{O}$ and $\mathrm{C}-\mathrm{H} \cdots \pi$ interactions as they are arranged in parallel, which are further connected to malonic acid and water molecules present in the channel by strong hydrogen bonds (Figure 5c).

Powder X-Ray Diffraction. The overlay of calculated patterns from the single crystal on the experimental powder XRD pattern confirms the homogeneity and purity of newly formed salts of AMX with fumaric acid, maleic acid, succinic acid, and malonic acid (Figures S30-S33; Supporting Information). Microcrystalline powder of all salts of AMX were formed by ethanol by grinding 5-6 times. The powder pattern of AMX, the corresponding acid, and salts are shown in Figures S1-S9, Supporting Information. Generation of a new salt through solvent-assisted grinding has been confirmed by the PXRD pattern of the product of the grinding experiment. The PXRD patterns of all of the salts were found to be different from those of the starting materials, and also no peak of the starting material was found as that of the impurity. The comparison of simulated PXRD pattern of the salt from the corresponding single crystal data and the experimental PXRD pattern of the same salt indicated that the hydrated salts $(3,6$, and 8) have a different PXRD pattern compared to that of the crude material, whereas the pattern of anhydrous salt (5) found by single-crystal X-ray diffraction matched that of the crude material. The difference in the powder pattern compared to that of AMX and acid indicated the formation of a novel solid form, which is supported by differential scanning calorimetry (DSC) (Figures S33-S42, Supporting Information).

IR Spectroscopy. In AMX salts, proton is transferred from acid to the nitrogen of piperazine ring of AMX. Generally,
$\mathrm{COOH}$ group stretching frequency occurs at $1730-1700 \mathrm{~cm}^{-1}$ and $\mathrm{COO}^{-}$group absorbs around $1600 \mathrm{~cm}^{-1}$ (asymmetric). $\mathrm{N}-\mathrm{H}$ absorption peak for the salt comes at $3400-3100 \mathrm{~cm}^{-1}$ (stretching) and $1610-1550 \mathrm{~cm}^{-1}$ (bending). $\mathrm{C}-\mathrm{N}$ absorption peak appears at $1350-1000 \mathrm{~cm}^{-1}$ (Table S1 and Figures S20S29). By this data, it is understood that new salts of the AMX are formed and proton is transferred to the nitrogen of API.

Thermal Analysis. Amoxapine displayed a sharp endothermic reaction at $183.1{ }^{\circ} \mathrm{C}$ without any phase transformation. Salts of AMX with D-(-)-tartaric acid, fumaric acid, D$(+)$-tartaric acid, maleic acid, succinic acid, citric acid, malonic acid, L-malic acid, and adipic acid show melting points at 147.2, 127.2, 147.1, 183.3, 95.8, 209.5, 162.3, 173.0, and $193.0{ }^{\circ} \mathrm{C}$, respectively. Citrate salt of AMX has shown the highest melting point of $209.5^{\circ} \mathrm{C}$, and succinate salt of AMX has displayed the lowest melting point of $95.8^{\circ} \mathrm{C}$. DSC thermograms are given in Supporting Information, Figures S34-S43, and melting point and melting enthalpies are listed in Table 4.

Solubility Study. AMX (a biopharmaceutics classification system class II drug) has poor solubility in water $(0.171 \mathrm{mg} /$ $\mathrm{mL}) .{ }^{34}$ Hence, it limits the pharmacokinetic and pharmacodynamic parameters of API, which exert effect on the intrinsic dissolution rate and bioavailability. Enhancement of solubility by help of crystal engineering of AMX with acids has been observed. A solubility experiment of AMX and its salts was performed in double-distilled water at $37{ }^{\circ} \mathrm{C}$ to determine the aqueous solubility. The solubility of each salt after $24 \mathrm{~h}$ is measured by plotting a calibration curve using UV-visible spectroscopy (Figures S10-S19). Solubilities of AMX and its salts have been displayed in Table 5. The solubility of AMX has increased by 4.5-60.4 times for its salts, as shown in Figure 6 . 

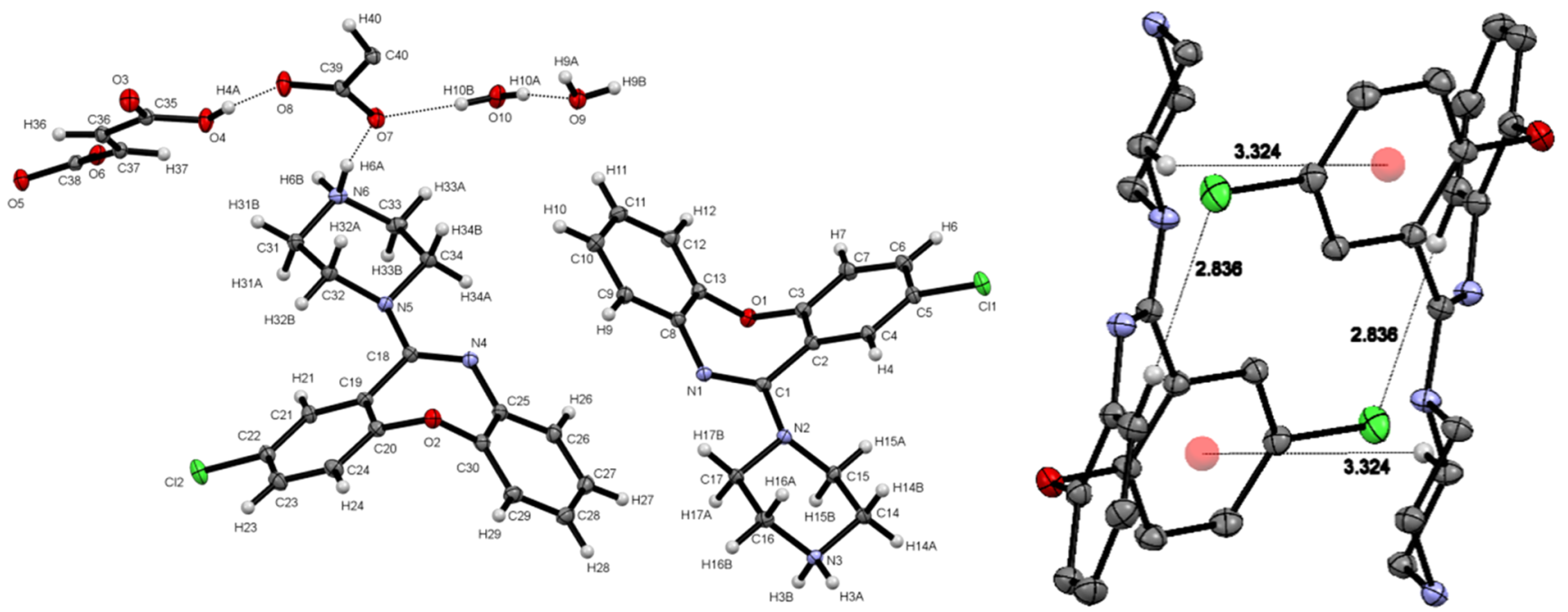

(a)

(b)

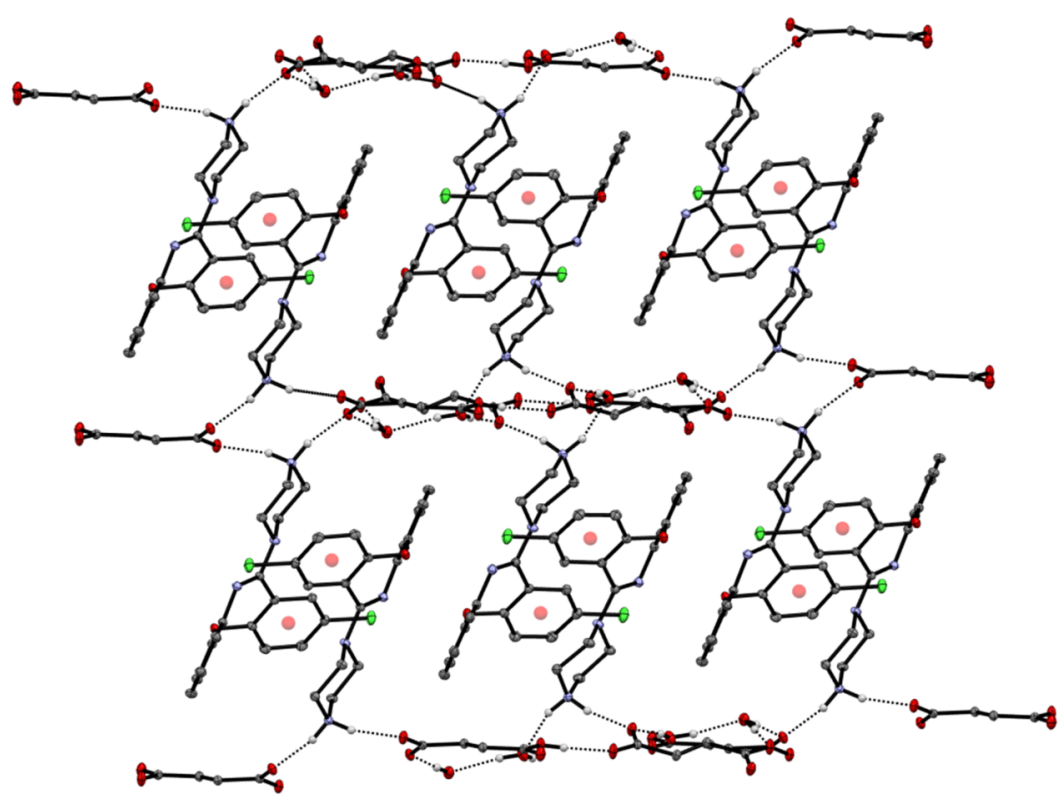

(c)

Figure 2. (a) Asymmetric unit of AMX/fumaric acid cocrystal. (b) Intralayer interaction between drug molecules. (c) Layers of AMX and fumaric acid-water channel in crystal packing.

The highest solubility is observed in L-malic acid salt of AMX $(23.5 \mathrm{mg} / \mathrm{mL})$ and lowest in citrate salt of AMX $(1.8 \mathrm{mg} / \mathrm{mL})$.

\section{DISCUSSION}

We have been successful in growing single crystals of four salts out of nine and determined their structures. The crystal structures of these four salts have common features in the packing of ions and solvents. AMX/fumaric acid salt and AMX/ succinic acid salt have an alternate arrangement of $\mathrm{AMX}^{+}$layer and acid-water channel due to the antiparallel arrangement of $\mathrm{AMX}^{+}$in the same layer providing binding sites for the respective carboxylate anion or water molecule to form strong hydrogen bonds. Therefore, these salts have lower melting points than those of other salts, as $\mathrm{AMX} /$ fumaric acid salt has a melting point $127.2{ }^{\circ} \mathrm{C}$, which is higher than that of AMX/ succinic acid $\left(95.8{ }^{\circ} \mathrm{C}\right)$ because AMX layer follows more regularity in AMX/fumaric acid salt. They can be differentiated by melting enthalpies also; $\mathrm{AMX} /$ fumaric acid salt has less melting enthalpy $(13.9 \mathrm{~J} / \mathrm{g})$ than that of $\mathrm{AMX} /$ succinic acid salt $(23.4 \mathrm{~J} / \mathrm{g})$. In the case of $\mathrm{AMX} /$ maleic acid salt and AMX/ malonic acid salt, single crystals have different patterns; two layers of AMX are present in between the acid layer in the case of AMX/maleic acid and acid-water channel in AMX/malonic acid salt. In both cases, the melting point is higher than that of previous salts (Table 4). The melting point difference between these two salts may be due to the additional $\pi-\pi$ stacking present in $\mathrm{AMX} /$ maleic acid cocrystal along with $\mathrm{C}-\mathrm{H} \cdots \pi$ interaction between two layers of AMX. However, AMX/ malonic acid cocrystal has only $\mathrm{C}-\mathrm{H} \cdots \pi$ interaction. Among these four salts, $\mathrm{AMX} / \mathrm{maleic}$ acid salt has the lowest solubility, 


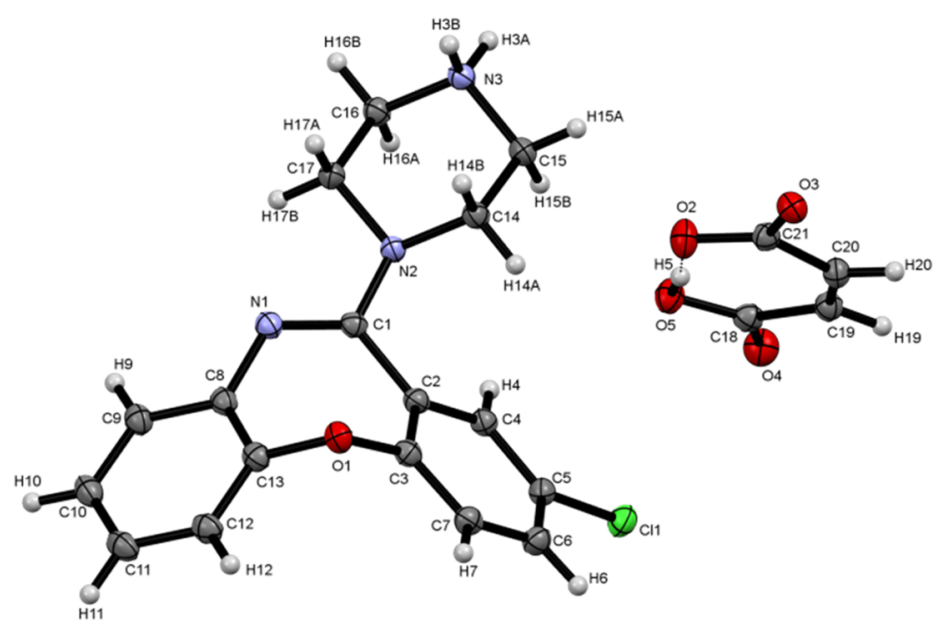

(a)

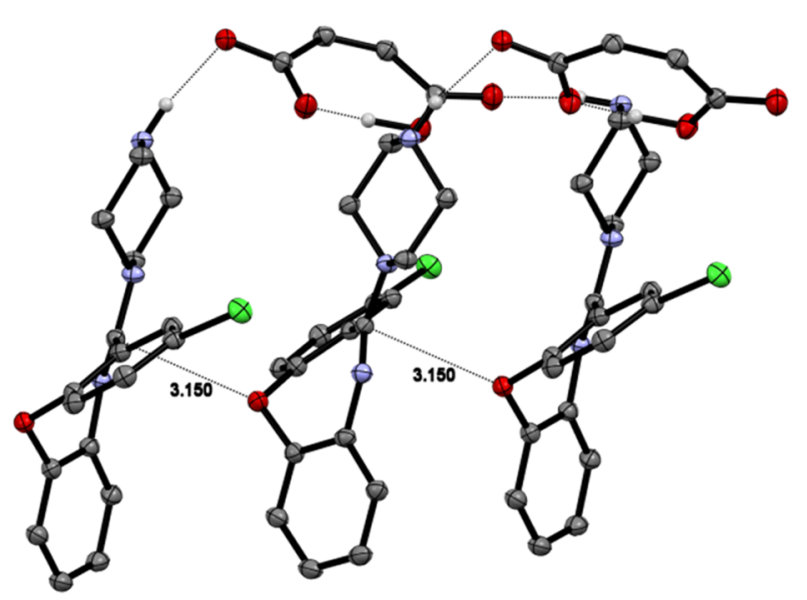

(b)

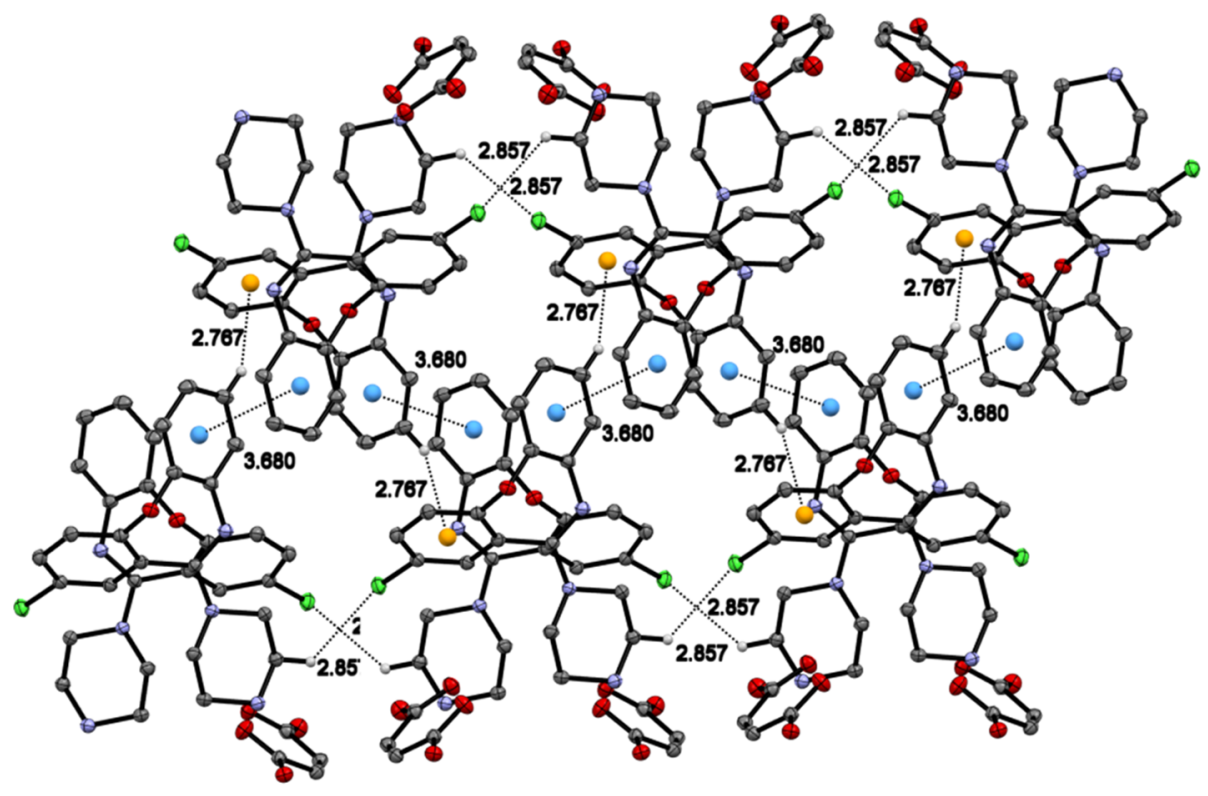

(c)

Figure 3. (a) Asymmetric unit of AMX/maleic acid cocrystal. (b) Intralayer interaction of AMX along $b$ axis. (c) Interlayer interactions along $c$ axis and layers of AMX and maleic acid in crystal packing.

$2.7 \mathrm{mg} / \mathrm{mL}$, but others have higher solubilities (Table 5). $\mathrm{AMX} /$ maleic acid salt is anhydrous, but the other three are hydrated. This may be attributed to the higher solubility of these three (AMX/fumaric acid salt, AMX/succinic acid salt, and $\mathrm{AMX} /$ malonic acid salt).

\section{CONCLUSIONS}

We have synthesized nine novel salts of amoxapine by a rational use of the $\Delta \mathrm{p} K_{\mathrm{a}}$ rule of 3 . We have found four single crystals of AMX salt with fumaric acid, maleic acid, succinic acid, and malonic acid, with solved structures by single-crystal XRD. In salt structures, the proton of acid is transferred to the nitrogen of piperazine ring in AMX by ionic $\mathrm{N}^{+}-\mathrm{H} \cdots \mathrm{O}^{-}$hydrogen bond. A solubility experiment was performed in double-distilled water at $37{ }^{\circ} \mathrm{C}$ for all salts of AMX and pure API. We have found many-fold increments in solubility, i.e., 4.5- to 60.4-fold. This introductory study encourages us for further experiment of soluble salts of amoxapine for antidepressant activity in vivo and in vitro in future.

\section{EXPERIMENTAL SECTION}

Materials. Amoxapine was purchased from Sigma-Aldrich and used without further purification. The cocrystal formers were obtained from various commercial suppliers, such as Adipic acid from Sigma-Aldrich; D-(-)-tartaric acid from Spectrochem Pvt. Ltd., India; fumaric acid, maleic acid, and succinic acid from Sisco Research Laboratories Pvt. Ltd., India; (+)tartaric acid from Qualigens Fine Chemicals Pvt. Ltd., India; and citric acid, malonic acid, and L-malic acid from HIMEDIA Laboratories Pvt. Ltd., India. Analytical grade solvents ethanol 


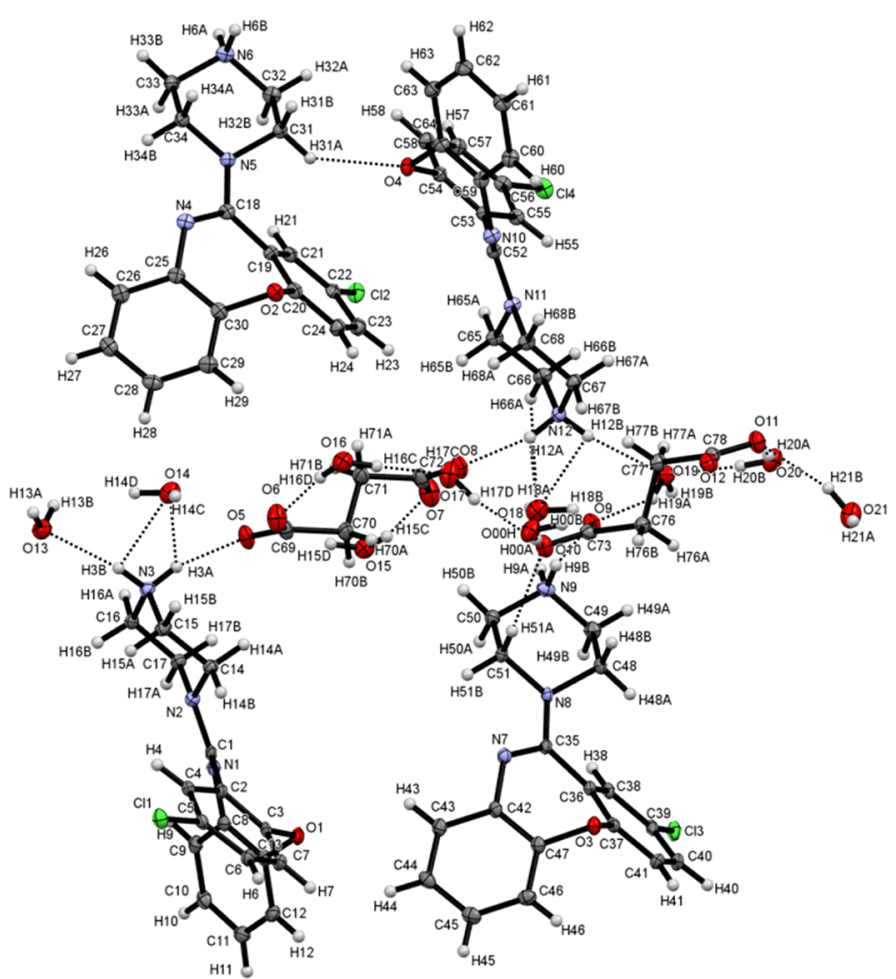

(a)

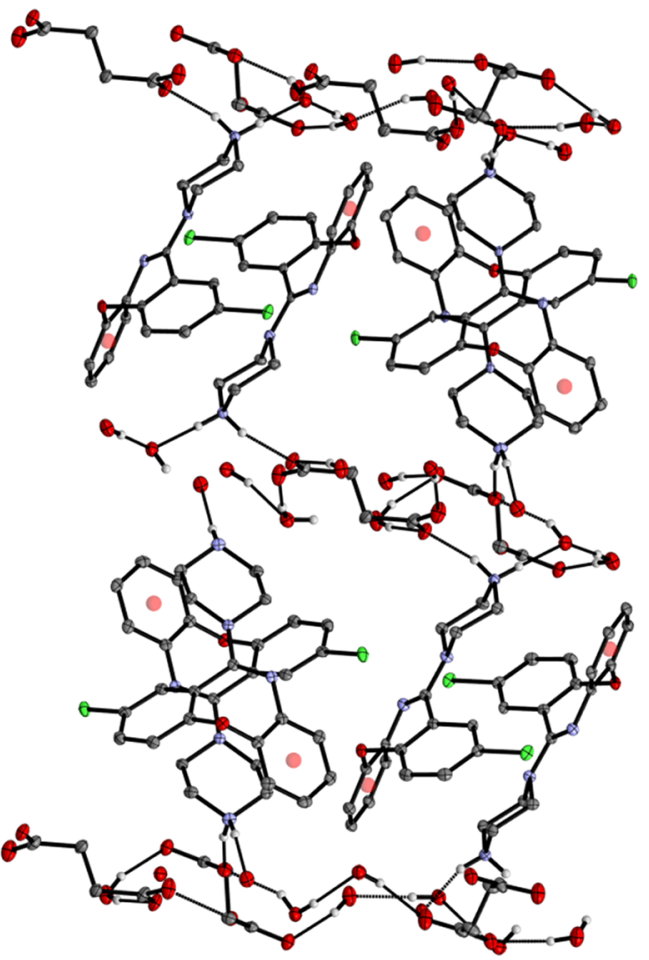

(c)

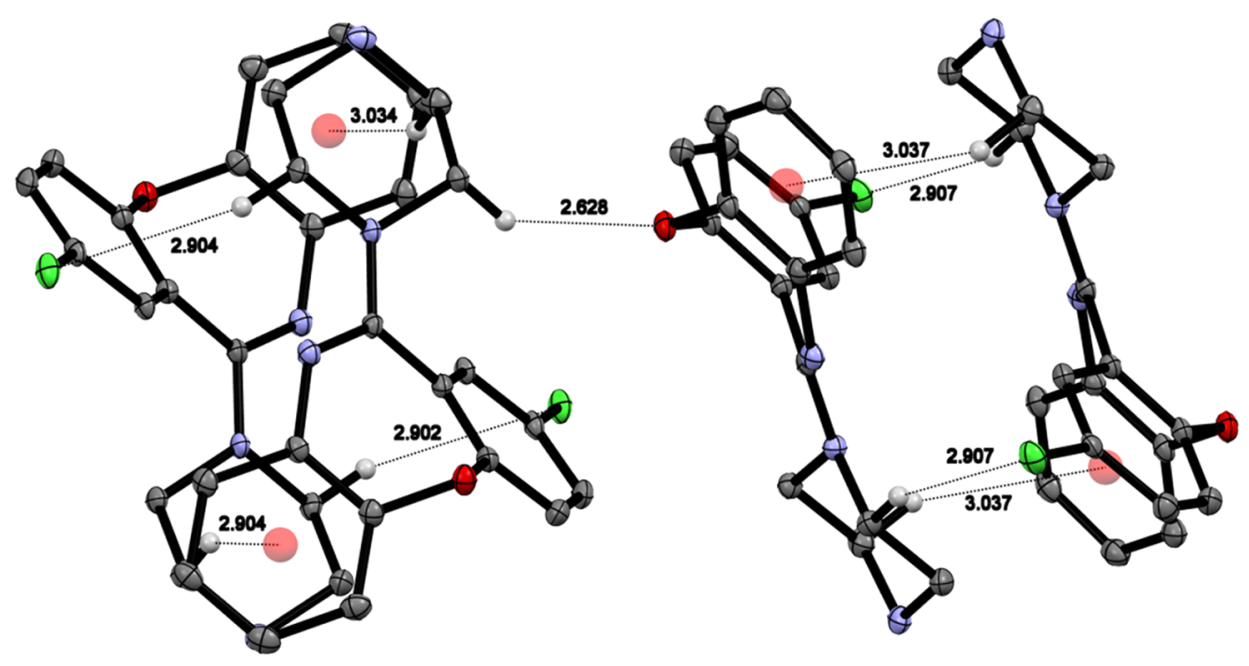

(b)

Figure 4. (a) Asymmetric unit of AMX/succinic acid cocrystal. (b) Intralayer interaction of AMX molecules. (c) Layers of AMX and succinic acidwater channel in crystal packing.

and methanol were obtained from Merck, Millipore Corporation.

Solvent-Drop Grinding Method and Slow Evaporation Method. The salts were synthesized by the solvent-drop grinding method. An equimolar mixture of the API and a cocrystal former (one among maleic acid, fumaric acid, citric acid, succinic acid, D-(-)-tartaric acid, (+)-tartaric acid, adipic acid, L-malic acid, and malonic acid) was made by accurate weighing. Hundred microliters of ethanol was added to the mixture using a micropipette and was ground in agate mortar and pestle till free-flowing powder was formed. The same process was followed about 5-6 times till a new single phase was obtained. Powder X-ray diffraction data were recorded after a new single phase was obtained (Figures S1-S9, Supporting Information). Once a new single phase was formed, the resulting mixture was used for Fourier transform infrared (FTIR) (Figures S20-S29, Table S1, Supporting Information) and DSC (Figures S34-S43, Supporting Information) (Table 4); a portion was dissolved in various solvent systems and kept for the growth of the single crystal by a slow evaporation 


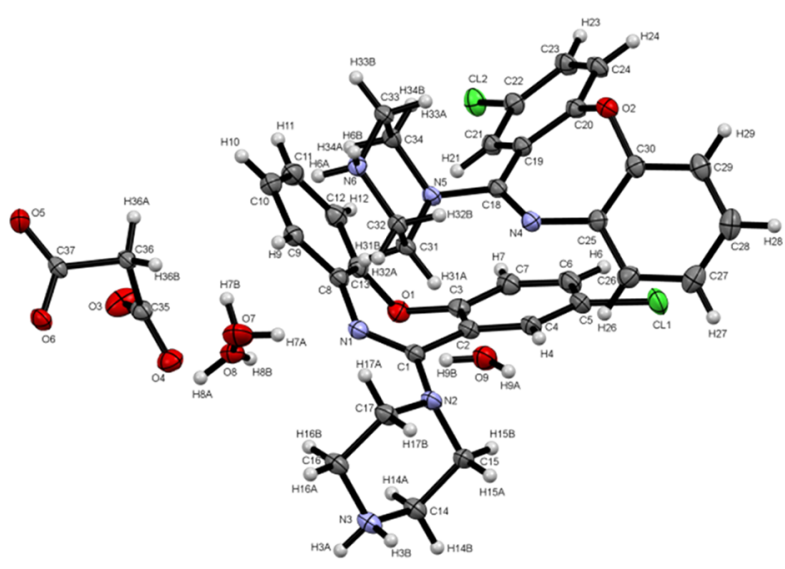

(a)

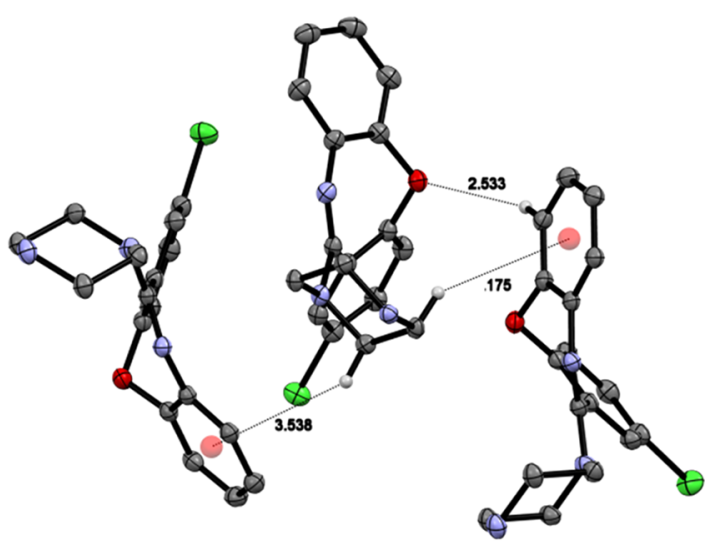

(b)

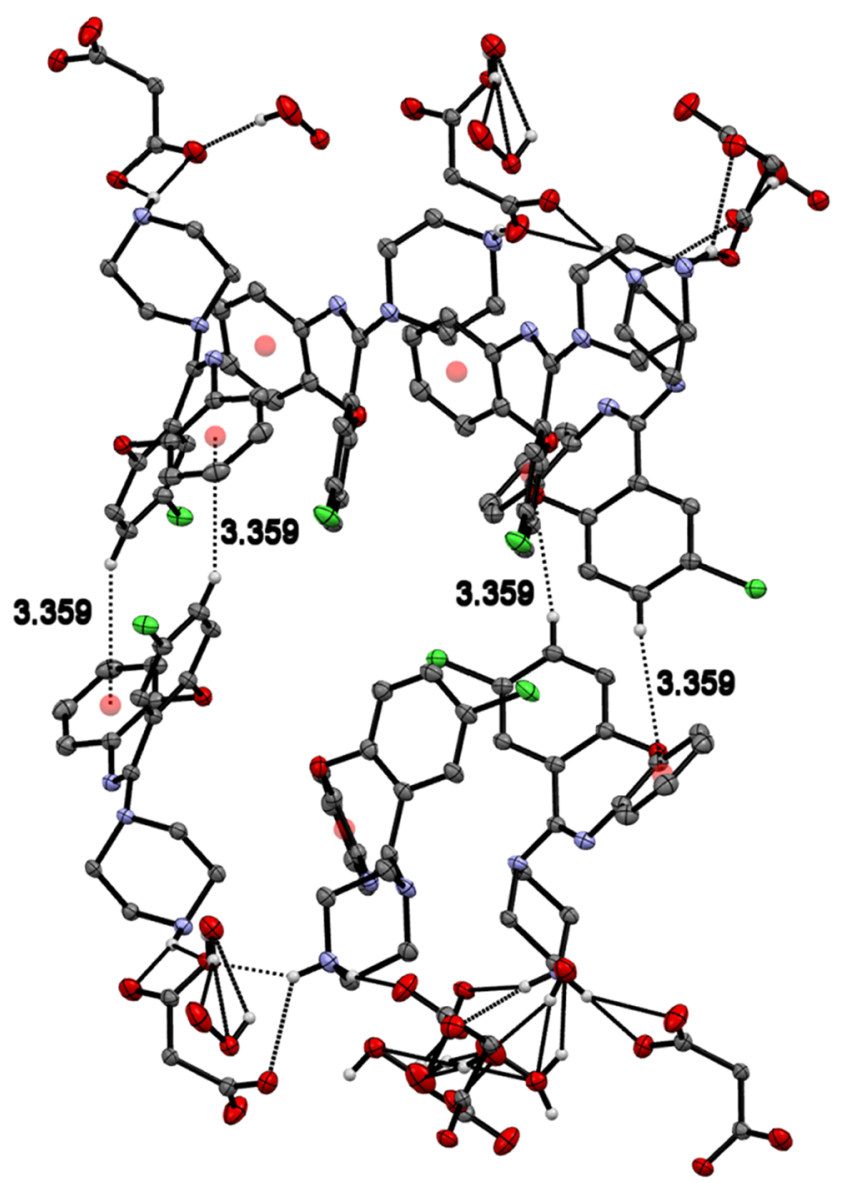

(c)

Figure 5. (a) Asymmetric unit of AMX/malonic acid salt. (b) Intralayer interaction of AMX. (c) Layers of AMX and malonic acid-water channel in crystal packing.

process and was also used for the determination of saturation solubility.

Powder X-Ray Diffraction (PXRD). PXRD data were recorded on a Rigaku Ultima IV diffractometer using parallel beam geometry equipped with a $\mathrm{Cu} \mathrm{K} \alpha$ source, $2.5^{\circ}$ primary and secondary solar slits, a $5^{\circ}$ in-plane divergence slit with a 10 $\mathrm{mm}$ height limit of the slit, a sample rotation stage (120 rpm) attachment, and a DTex Ultra detector. The data were collected over the $2 \theta$ range of $5-50^{\circ}$ with a scanning speed of $2^{\circ} / \mathrm{min}$, with $0.02^{\circ}$ steps. PXRD patterns are shown in the Figures S1S9, Supporting Information.

FTIR Spectroscopy. FTIR spectra of APIs and their complexes were recorded on a PerkinElmer Spectrum Two FTIR spectrometer in the range of $400-4000 \mathrm{~cm}^{-1}$. Samples were prepared using dry $\mathrm{KBr}$ in the form of a pellet, and data 
Table 3. Hydrogen Bond Geometry Parameters in Salts of AMX

\begin{tabular}{|c|c|c|c|c|c|c|}
\hline salts & interactions & $\mathrm{D}-\mathrm{H}(\AA)$ & $\mathrm{H} \cdots \mathrm{A}(\AA)$ & $\mathrm{D} \cdots \mathrm{A}(\AA)$ & $\mathrm{D}-\mathrm{H} \cdots \mathrm{A}(\mathrm{deg})$ & symmetry code \\
\hline \multirow[t]{16}{*}{ AMX/fumaric acid (1:1) } & $\mathrm{N} 3-\mathrm{H} 3 \mathrm{~A} \cdots \mathrm{O} 6$ & 0.91 & 1.81 & $2.703(1)$ & 166 & $-1+x, 1+y,-1+z$ \\
\hline & $\mathrm{N} 3-\mathrm{H} 3 \mathrm{~B} \cdots \mathrm{O} 5$ & 0.91 & 1.93 & $2.821(1)$ & 165 & $1-x,-y, 1-z$ \\
\hline & $\mathrm{O} 4-\mathrm{H} 4 \mathrm{~A} \cdots \mathrm{O} 8$ & 0.84 & 1.79 & $2.623(1)$ & 173 & $1-x,-y, 1-z$ \\
\hline & 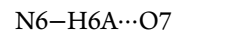 & 0.91 & 1.82 & $2.717(1)$ & 167 & $1-x,-y, 1-z$ \\
\hline & N6-H6B $\cdots \mathrm{O} 10$ & 0.91 & 1.84 & $2.712(1)$ & 160 & $1-x,-1-y, 1-z$ \\
\hline & 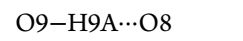 & 0.85 & 1.98 & $2.817(1)$ & 166 & $-x,-1-y, 1-z$ \\
\hline & 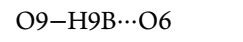 & 0.85 & 1.95 & $2.804(1)$ & 179 & $1-x,-1-y, 1-z$ \\
\hline & O10-H10A‥O9 & 0.85 & 1.91 & $2.756(1)$ & 173 & $1-x,-1-y, 1-z$ \\
\hline & 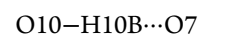 & 0.85 & 1.91 & $2.747(1)$ & 171 & $1-x,-1-y, 1-z$ \\
\hline & $\mathrm{C} 14-\mathrm{H} 14 \mathrm{~A} \cdots \mathrm{O} 3$ & 0.99 & 2.47 & $3.193(1)$ & 129 & $x, 1+y,-1+z$ \\
\hline & $\mathrm{C} 15-\mathrm{H} 15 \mathrm{~B} \cdots \mathrm{O} 1$ & 0.99 & 2.58 & $3.142(1)$ & 116 & $1-x,-y,-z$ \\
\hline & $\mathrm{C} 16-\mathrm{H} 16 \mathrm{~B} \cdots \mathrm{O} 3$ & 0.99 & 2.57 & $3.531(1)$ & 163 & $-x,-y, 1-z$ \\
\hline & $\mathrm{C} 31-\mathrm{H} 31 \mathrm{~B} \cdots \mathrm{O} 4$ & 0.99 & 2.45 & $3.271(1)$ & 140 & $-x,-y, 1-z$ \\
\hline & $\mathrm{C} 32-\mathrm{H} 32 \mathrm{~B} \cdots \mathrm{Cl} 1$ & 0.99 & 2.74 & $3.543(1)$ & 139 & $x, y, 1+z$ \\
\hline & $\mathrm{C} 37-\mathrm{H} 37 \cdots \mathrm{O} 4$ & 0.95 & 2.42 & $2.755(1)$ & 101 & $x, y, 1+z$ \\
\hline & $\mathrm{C} 17-\mathrm{H} 17 \cdots \pi$ & 0.99 & 3.32 & & 127 & \\
\hline \multirow[t]{10}{*}{ AMX/maleic acid (1:1) } & $\mathrm{N} 3-\mathrm{H} 3 \mathrm{~A} \cdots \mathrm{O} 3$ & 0.89 & 2.55 & $2.910(2)$ & 105 & $-x,-1 / 2+y, 3 / 2-z$ \\
\hline & $\mathrm{N} 3-\mathrm{H} 3 \mathrm{~A} \cdots \mathrm{O} 3$ & 0.89 & 1.89 & $2.767(2)$ & 167 & $x, 3 / 2-y,-1 / 2+z$ \\
\hline & $\mathrm{N} 3-\mathrm{H} 3 \mathrm{~B} \cdots \mathrm{O} 4$ & 0.89 & 1.91 & $2.793(2)$ & 171 & $x, 3 / 2-y, 1 / 2+z$ \\
\hline & $\mathrm{O} 2-\mathrm{H} 5 \cdots \mathrm{O} 5$ & $1.36(4)$ & $1.07(4)$ & $2.426(2)$ & 170 & $x, 3 / 2-y, 1 / 2+z$ \\
\hline & $\mathrm{C} 14-\mathrm{H} 14 \mathrm{~A} \cdots \mathrm{O} 2$ & 0.97 & 2.58 & $3.188(2)$ & 121 & $x, 3 / 2-y, 1 / 2+z$ \\
\hline & $\mathrm{C} 15-\mathrm{H} 15 \mathrm{~A} \cdots \mathrm{O} 2$ & 0.97 & 2.57 & $3.150(2)$ & 118 & $x, 3 / 2-y, 1 / 2+z$ \\
\hline & $\mathrm{C} 15-\mathrm{H} 15 \mathrm{~B} \cdots \mathrm{O} 5$ & 0.97 & 2.57 & $3.165(2)$ & 120 & $x, 3 / 2-y, 1 / 2+z$ \\
\hline & $\mathrm{C} 19-\mathrm{H} 19 \cdots \mathrm{O} 3$ & 0.93 & 2.37 & $3.269(2)$ & 162 & $x, 5 / 2-y,-1 / 2+z$ \\
\hline & $\mathrm{C} 16-\mathrm{H} 16 \mathrm{~B} \cdots \mathrm{Cl1}$ & 0.97 & 2.86 & & 128 & \\
\hline & $\mathrm{C} 10-\mathrm{H} 10 \cdots \pi$ & 0.93 & 2.76 & & 155 & \\
\hline \multirow[t]{30}{*}{ AMX/succinic acid (1:1) } & $\mathrm{O} 00 \mathrm{H}-\mathrm{H} 00 \mathrm{~A} \cdots \mathrm{O} 10$ & 0.85 & 1.93 & $2.771(3)$ & 171 & $x, 1 / 2-y, 1 / 2+z$ \\
\hline & $\mathrm{N} 3-\mathrm{H} 3 \mathrm{~A} \cdots \mathrm{O} 5$ & 0.89 & 1.86 & $2.734(3)$ & 165 & $x, 1 / 2-y, 1 / 2+z$ \\
\hline & $\mathrm{N} 3-\mathrm{H} 3 \mathrm{~B} \cdots \mathrm{O} 13$ & 0.89 & 2.09 & $2.888(3)$ & 149 & $x, 1 / 2-y, 1 / 2+z$ \\
\hline & N6-H6A ‥O14 & 0.89 & 1.84 & $2.701(3)$ & 162 & $2-x, 1-y, 1-z$ \\
\hline & $\mathrm{N} 6-\mathrm{H} 6 \mathrm{~B} \cdots \mathrm{O} 12$ & 0.89 & 1.83 & $2.699(3)$ & 167 & $1-x, 1-y, 1-z$ \\
\hline & N9-H9A ‥O18 & 0.89 & 1.82 & $2.681(3)$ & 162 & $1-x, 1-y, 1-z$ \\
\hline & 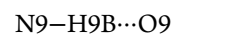 & 0.89 & 1.83 & $2.709(3)$ & 167 & $1-x, 1-y, 1-z$ \\
\hline & $\mathrm{N} 12-\mathrm{H} 12 \mathrm{~A} \cdots \mathrm{O} 8$ & 0.89 & 1.86 & $2.732(3)$ & 165 & $1-x, 1-y, 1-z$ \\
\hline & $\mathrm{N} 12-\mathrm{H} 12 \mathrm{~B} \cdots \mathrm{O} 19$ & 0.89 & 2.10 & $2.907(3)$ & 150 & $1-x, 1-y, 1-z$ \\
\hline & $\mathrm{O} 13-\mathrm{H} 13 \mathrm{~B} \cdots \mathrm{O} 12$ & 0.85 & 1.99 & $2.749(2)$ & 148 & $1+x, y, z$ \\
\hline & $\mathrm{O} 14-\mathrm{H} 14 \mathrm{C} \cdots \mathrm{O} 20$ & 0.85 & 1.93 & $2.731(3)$ & 157 & $1-x, 1 / 2+y, 1 / 2-z$ \\
\hline & $\mathrm{O} 15-\mathrm{H} 15 \mathrm{C} \cdots \mathrm{O} 7$ & 0.85 & 1.98 & $2.816(3)$ & 167 & $1-x, 1 / 2+y, 1 / 2-z$ \\
\hline & $\mathrm{O} 16-\mathrm{H} 16 \mathrm{C} \cdots \mathrm{O} 17$ & 0.85 & 1.99 & $2.830(3)$ & 170 & $1-x, 1 / 2+y, 1 / 2-z$ \\
\hline & $\mathrm{O} 16-\mathrm{H} 16 \mathrm{D} \cdots \mathrm{O} 6$ & 0.85 & 1.97 & $2.818(3)$ & 172 & $1-x, 1 / 2+y, 1 / 2-z$ \\
\hline & $\mathrm{O} 17-\mathrm{H} 17 \mathrm{C} \cdots \mathrm{O} 8$ & 0.85 & 1.95 & $2.794(3)$ & 170 & $1-x, 1 / 2+y, 1 / 2-z$ \\
\hline & $\mathrm{O} 17-\mathrm{H} 17 \mathrm{D} \cdots \mathrm{O} 10$ & 0.85 & 2.02 & $2.853(3)$ & 167 & $1-x, 1 / 2+y, 1 / 2-z$ \\
\hline & 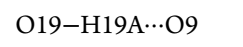 & 0.85 & 1.97 & $2.739(3)$ & 150 & $1-x, 1 / 2+y, 1 / 2-z$ \\
\hline & $\mathrm{O} 20-\mathrm{H} 20 \mathrm{~A} \cdots \mathrm{O} 11$ & 0.85 & 1.93 & $2.779(3)$ & 177 & $1-x, 1 / 2+y, 1 / 2-z$ \\
\hline & $\mathrm{O} 20-\mathrm{H} 20 \mathrm{~B} \cdots \mathrm{O} 19$ & 0.85 & 2.11 & $2.954(3)$ & 173 & $1-x, 1 / 2+y, 1 / 2-z$ \\
\hline & $\mathrm{O} 21-\mathrm{H} 21 \mathrm{~B} \cdots \mathrm{O} 11$ & 0.85 & 2.04 & $2.860(3)$ & 163 & $1-x, 1 / 2+y, 1 / 2-z$ \\
\hline & $\mathrm{C} 17-\mathrm{H} 17 \mathrm{~A} \cdots \mathrm{N} 1$ & 0.97 & 2.31 & $2.685(3)$ & 102 & $1-x, 1 / 2+y, 1 / 2-z$ \\
\hline & $\mathrm{C} 31-\mathrm{H} 31 \mathrm{~A} \cdots \mathrm{O} 4$ & 0.97 & 2.57 & $3.377(3)$ & 141 & $1-x, 1 / 2+y, 1 / 2-z$ \\
\hline & $\mathrm{C} 34-\mathrm{H} 34 \mathrm{~A} \cdots \mathrm{O} 11$ & 0.97 & 2.58 & $3.511(3)$ & 160 & $1-x, 1-y, 1-z$ \\
\hline & $\mathrm{C} 34-\mathrm{H} 34 \mathrm{~B} \cdots \mathrm{N} 4$ & 0.97 & 2.35 & $2.704(3)$ & 101 & $1-x, 1-y, 1-z$ \\
\hline & $\mathrm{C} 51-\mathrm{H} 51 \mathrm{~A} \cdots \mathrm{O} 10$ & 0.97 & 2.57 & $3.510(3)$ & 162 & $1-x, 1-y, 1-z$ \\
\hline & $\mathrm{C} 51-\mathrm{H} 51 \mathrm{~B} \cdots \mathrm{N} 7$ & 0.97 & 2.34 & $2.692(3)$ & 101 & $1-x, 1-y, 1-z$ \\
\hline & $\mathrm{C} 65-\mathrm{H} 65 \mathrm{~A} \cdots \mathrm{O} 1$ & 0.97 & 2.60 & $3.426(3)$ & 144 & $x, 1 / 2-y, 1 / 2+z$ \\
\hline & $\mathrm{C} 68-\mathrm{H} 68 \mathrm{~B} \cdots \mathrm{N} 10$ & 0.97 & 2.31 & $2.688(3)$ & 102 & $x, 1 / 2-y, 1 / 2+z$ \\
\hline & $\mathrm{C} 49-\mathrm{H} 49 \mathrm{~B} \cdots \pi$ & 0.97 & & 3.037 & 155 & \\
\hline & С66-H66B $\cdots \pi$ & 0.97 & & 2.904 & 152 & \\
\hline \multirow[t]{6}{*}{ AMX/malonic acid (1:1) } & $\mathrm{N} 3-\mathrm{H} 3 \mathrm{~A} \cdots \mathrm{O} 4$ & 0.89 & 2.50 & $3.109(3)$ & 126 & $1-x, 1 / 2+y, 3 / 2-z$ \\
\hline & $\mathrm{N} 3-\mathrm{H} 3 \mathrm{~A} \cdots \mathrm{O} 6$ & 0.89 & 2.20 & $2.883(3)$ & 133 & $1-x, 1 / 2+y, 3 / 2-z$ \\
\hline & $\mathrm{N} 3-\mathrm{H} 3 \mathrm{~B} \cdots \mathrm{O} 3$ & 0.89 & 1.86 & $2.737(3)$ & 166 & $x, 1+y, z$ \\
\hline & 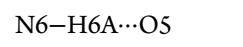 & 0.89 & 1.85 & $2.717(3)$ & 163 & $1-x,-y, 1-z$ \\
\hline & N6-H6A ‥O6 & 0.89 & 2.56 & $3.289(2)$ & 139 & $1-x,-y, 1-z$ \\
\hline & \multicolumn{5}{|c|}{2413} & $\begin{array}{l}\text { DOI: } 10.1021 / \text { acsomega. } 7 \mathrm{~b} 0202 \\
\text { ACS Omega 2018, 3, 2406-241 }\end{array}$ \\
\hline
\end{tabular}


Table 3. continued

\begin{tabular}{|c|c|c|c|c|c|c|}
\hline salts & interactions & $\mathrm{D}-\mathrm{H}(\AA)$ & $\mathrm{H} \cdots \mathrm{A}(\AA)$ & $\mathrm{D} \cdots \mathrm{A}(\AA)$ & $\mathrm{D}-\mathrm{H} \cdots \mathrm{A}(\mathrm{deg})$ & symmetry code \\
\hline & $\mathrm{N} 6-\mathrm{H} 6 \mathrm{~B} \cdots \mathrm{O} 3$ & 0.89 & 2.49 & $3.122(3)$ & 128 & $x, 1 / 2-y,-1 / 2+z$ \\
\hline & $\mathrm{N} 6-\mathrm{H} 6 \mathrm{~B} \cdots \mathrm{O} 4$ & 0.89 & 1.87 & $2.753(3)$ & 171 & $x, 1 / 2-y,-1 / 2+z$ \\
\hline & $\mathrm{O} 8-\mathrm{H} 8 \mathrm{~A} \cdots \mathrm{O} 9$ & 0.85 & 2.33 & $2.897(3)$ & 125 & $1-x, 1-y, 1-z$ \\
\hline & $\mathrm{O} 8-\mathrm{H} 8 \mathrm{~B} \cdots \mathrm{O} 4$ & 0.85 & 2.51 & $2.946(3)$ & 112 & $1-x, 1-y, 1-z$ \\
\hline & O9-H9A $\cdots$ O6 & 0.85 & 2.00 & $2.837(3)$ & 169 & $1-x, 1-y, 1-z$ \\
\hline & O9-H9B $\cdots$ O 8 & 0.85 & 2.07 & $2.897(3)$ & 165 & $1-x, 1-y, 1-z$ \\
\hline & O9-H9B $\cdots$ O7 & 0.85 & 1.93 & $2.737(11)$ & 158 & $1-x, 1-y, 1-z$ \\
\hline & $\mathrm{C} 10-\mathrm{H} 10 \cdots \mathrm{O} 9$ & 0.93 & 2.56 & $3.486(3)$ & 176 & $x,-1+y, z$ \\
\hline & $\mathrm{C} 12-\mathrm{H} 12 \cdots \mathrm{O} 2$ & 0.93 & 2.53 & $3.238(3)$ & 133 & $x, 1 / 2-y, 1 / 2+z$ \\
\hline & $\mathrm{C} 32-\mathrm{H} 32 \mathrm{~A} \cdots \mathrm{O} 8$ & 0.97 & 2.57 & $3.506(3)$ & 162 & $1-x, 1-y, 1-z$ \\
\hline & $\mathrm{C} 32-\mathrm{H} 32 \mathrm{~A} \cdots \mathrm{O} 7$ & 0.97 & 2.55 & $3.400(11)$ & 146 & $1-x, 1-y, 1-z$ \\
\hline & $\mathrm{C} 32-\mathrm{H} 32 \mathrm{~B} \cdots \mathrm{O} 3$ & 0.97 & 2.57 & $3.069(3)$ & 112 & $x, 1 / 2-y,-1 / 2+z$ \\
\hline & С $33-\mathrm{H} 33 \mathrm{~A} \cdots \pi$ & 0.97 & & 3.175 & 145 & \\
\hline & С $34-\mathrm{H} 34 \mathrm{~A} \cdots \pi$ & 0.97 & & 3.538 & 127 & \\
\hline & $\mathrm{C} 23-\mathrm{H} 23 \cdots \pi$ & 0.93 & & 3.369 & 155 & \\
\hline
\end{tabular}

Table 4. Melting Point and Melting Enthalpies of AMX and Its Salts

\begin{tabular}{lccc}
\multicolumn{1}{c}{ name } & $\begin{array}{c}\text { melting point of } \\
\text { API/conformer }\left({ }^{\circ} \mathrm{C}\right)\end{array}$ & $\begin{array}{c}\text { melting point of salt } \\
\text { with AMX }\left({ }^{\circ} \mathrm{C}\right)\end{array}$ & $\begin{array}{c}\text { melting } \\
\text { enthalpies } \\
(\mathrm{J} / \mathrm{g})\end{array}$ \\
$\begin{array}{l}\text { amoxapine } \\
\begin{array}{l}\text { D- }(-) \text {-tartaric } \\
\text { acid }\end{array}\end{array}$ & 183.1 & 147.2 & 114.4 \\
fumaric acid & 173 & 127.2 & 83.0 \\
$\begin{array}{l}\text { D- }(+) \text {-tartaric } \\
\text { acid }\end{array}$ & 287 & 147.1 & 13.9 \\
maleic acid & 135 & 183.3 & 45.1 \\
succinic acid & 184 & 95.8 & 21.8 \\
citric acid & 153 & 209.5 & 23.4 \\
malonic acid & 135 & 162.3 & 442.6 \\
L-malic acid & 131 & 173.0 & 11.6 \\
adipic acid & 152 & 193.0 & 60.4 \\
\end{tabular}

Table 5. Solubility of AMX and Its Salts

\begin{tabular}{clc} 
s. no. & \multicolumn{1}{c}{ compound } & solubility $(\mathrm{mg} / \mathrm{mL})$ \\
1 & AMX & 0.4 \\
2 & AMX/D-(-)-tartaric acid & 5.8 \\
3 & AMX/fumaric acid & 10.7 \\
4 & AMX/D-(+)-tartaric acid & 6.1 \\
5 & AMX/maleic acid & 2.7 \\
6 & AMX/succinic acid & 4.7 \\
7 & AMX/citric acid & 1.8 \\
8 & AMX/malonic acid & 9.5 \\
9 & AMX/L-malic acid & 23.5 \\
10 & AMX/adipic acid & 4.7 \\
\hline
\end{tabular}

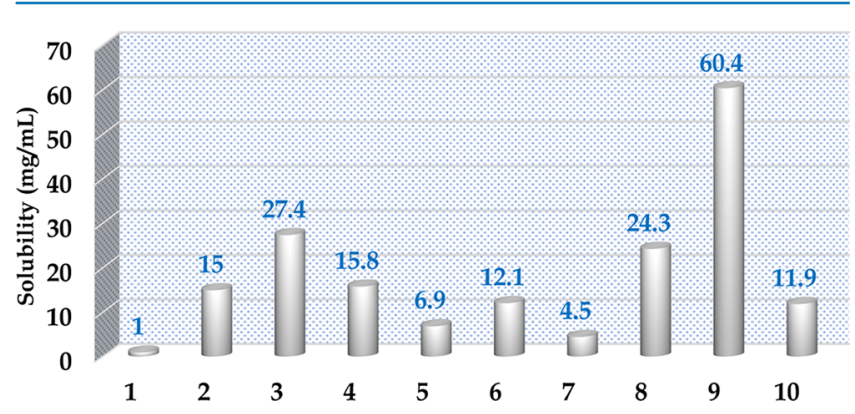

Figure 6. Enhancement in solubility of salts of AMX. were processed by using Spectrum software. ${ }^{35}$ Table S1 lists the FTIR peaks indicating the salt formation.

Thermal Analysis. The melting points (Table 4) and thermal properties of the complexes were determined by Perkin-Elmer DSC8000. All of the samples (2-5 mg) were heated at a $5{ }^{\circ} \mathrm{C} / \mathrm{min}$ heating rate in sealed aluminum pans. The melting points and the melting enthalpies of AMX and their salts are reported in the Table 4, and the DSC traces are reported in the Supporting Information (Figure S34-S43).

Solubility Analysis Using UV-Vis Spectroscopy. The solubility (at $37{ }^{\circ} \mathrm{C}$ ) of the salts and of the commercially available API was determined by using UV-vis spectroscopy, as reported by Karanam et al., ${ }^{17}$ by using the approach established by Higuchi and Connors. ${ }^{36}$ Initially, the calibration curve was drawn by using solutions of AMX of known concentrations of AMX and all salts at $\lambda_{\max }$ of $209 \mathrm{~nm}$ in water on a Lab India UV3000+ UV-vis spectrophotometer (Figures S10-S19). These absorbances were plotted against concentration, and a linear equation is determined for calculating unknown concentrations. Molar extinction coefficients of AMX and the salts were determined by the slope of the curve. Concurrently saturated solutions of each of the AMX and salts were prepared by stirring an excess amount of the compound/salt in $2 \mathrm{~mL}$ of deionized water in $5 \mathrm{~mL}$ sealed vials at $37{ }^{\circ} \mathrm{C}$ and stirred at $1500 \mathrm{rpm}$ for $24 \mathrm{~h}$. These solutions were then centrifuged at 10 $000 \mathrm{rpm}$ for $20 \mathrm{~min}$; then, the supernatant solution was diluted 1000 times using double-distilled water. The absorbance of the diluted solution was measured at $\lambda_{\max }(209 \mathrm{~nm})$ of the salt, and the concentration of the salt was determined using the calibration curve. The solubility was calculated by multiplying the concentration with a dilution factor. Table 5 lists the solubility of AMX and their novel salts.

Single-Crystal X-Ray Diffraction. Single-crystal X-ray diffraction data were collected using a Rigaku XtaLABmini Xray diffractometer equipped with a Mercury charge-coupled device detector with graphite monochromatic Mo K $\alpha$ radiation $(\lambda=0.71073 \AA)$ at $100.0(2) \mathrm{K}$ using $\omega$ scans. The data were reduced using CrysAlisPro 1.171.38.46, and the space group determination was done using Olex2. ${ }^{37}$ The crystal structures were solved by using ShelXT ${ }^{38}$ and were refined using ShelXL ${ }^{39}$ through Olex2 suite. All of the hydrogen atoms were geometrically fixed and refined using the riding model. Absorption correction was done by a multiscan method. Data collection, crystal structure solution, and refinement details for 
all of the salts are listed in Table 2. All of the packing and interaction diagrams have been generated using Mercury 3.9. ${ }^{40}$ Crystals of 1:1 salt of AMX with fumaric acid were obtained from a water/methanol $(1: 1)$ mixture at $4{ }^{\circ} \mathrm{C}$ in a refrigerator. Other crystals of AMX with maleic acid in a 1:1 salt were grown in a 1:1 water: ethanol mixture at $4{ }^{\circ} \mathrm{C}$. Crystals of AMX with succinic acid and malonic acid were prepared in water at $4{ }^{\circ} \mathrm{C}$. Good quality single crystals were obtained after 10-15 days.

\section{ASSOCIATED CONTENT}

\section{S Supporting Information}

The Supporting Information is available free of charge on the ACS Publications website at DOI: 10.1021/acsomega.7b02023.

PXRD patterns, DSC traces, and FTIR spectra (PDF) Crystallographic data for salts of AMX with fumaric acid, maleic acid, succinic acid, and malonic acid (CIF) (CIF) (CIF) (CIF)

\section{AUTHOR INFORMATION}

\section{Corresponding Author}

*E-mail: angshurc@iisermohali.ac.in.

ORCID

Angshuman Roy Choudhury: 0000-0002-4018-0451

Notes

The authors declare no competing financial interest.

\section{ACKNOWLEDGMENTS}

The authors thank IISER Mohali for funding, infrastructural facility, all of the instrumental facilities, including FTIR, XtaLABmini X-ray diffractometer, PXRD, DSC, computational facility, etc. M.J. thanks DST for INSPIRE fellowship (IF160793).

\section{REFERENCES}

(1) Desiraju, G. R. Crystal Engineering: A Holistic View. Angew. Chem., Int. Ed. 2007, 46, 8342-8356.

(2) Desiraju, G. R. Crystal Engineering: From Molecule to Crystal. J. Am. Chem. Soc. 2013, 135, 9952-9967.

(3) Eddaoudi, M.; Moler, D. B.; Li, H.; Chen, B.; Reineke, T. M.; O'Keeffe, M.; Yaghi, O. M. Modular Chemistry: Secondary Building Units as a Basis for the Design of Highly Porous and Robust MetalOrganic Carboxylate Frameworks. Acc. Chem. Res. 2001, 34, 319-330.

(4) Jones, J. T. A.; Hasell, T.; Wu, X.; Bacsa, J.; Jelfs, K. E.; Schmidtmann, M.; Chong, S. Y.; Adams, D. J.; Trewin, A.; Schiffman, F.; et al. Modular and Predictable Assembly of Porous Organic Molecular Crystals. Nature 2011, 474, 367-371.

(5) Salmon, D. J.; et al. Building Co-Crystals with Molecular Sense and Supramolecular Sensibility Highlight. CrystEngComm 2005, 7, 439-448.

(6) Thomas, J. M. Crystal Engineering: Origins, Early Adventures and Some Current Trends. CrystEngComm 2011, 13, No. 4304.

(7) Desiraju, G. R. A Bond by Any Other Name. Angew. Chem., Int. Ed. 2011, 50, 52-59.

(8) Hathwar, V. R.; Thakur, T. S.; Guru Row, T. N.; Desiraju, G. R. Transferability of Multipole Charge Density Parameters for Supramolecular Synthons: A New Tool for Quantitative Crystal Engineering. Cryst. Growth Des. 2011, 11, 616-623.

(9) Kastelic, J.; Lah, N.; Kikelj, D.; Leban, I. A 1:1 Cocrystal of Fluconazole with Salicylic Acid. Acta Crystallogr., Sect. C: Cryst. Struct. Commun. 2011, 67, o370-o372.

(10) Aitipamula, S.; Banerjee, R.; Bansal, A. K.; Biradha, K.; Cheney, M. L.; Choudhury, A. R.; Desiraju, G. R.; Dikundwar, A. G.; Dubey, R.; Duggirala, N.; Ghogale, P. P.; Ghosh, S.; Goswami, P. K.; Goud, N. R.; Jetti, R. K. R.; Karpinski, P.; Kaushik, P.; Kumar, D.; Kumar, V.;
Moulton, B.; Mukherjee, A.; Mukherjee, G.; Myerson, A. S.; Puri, V.; Ramanan, A.; Rajamannar, T.; Reddy, C. M.; Hornedo, N. R.; Rogers, R. D.; Row, T. N. G.; Sanphui, P.; Shan, N.; Shete, G.; Singh, A.; Sun, C. C.; Swift, J. A.; Thaimattam, R.; Thakur, T. S.; Thaper, R. K.; Thomas, S. P.; Tothadi, S.; Vangala, V. R.; Variankaval, N.; Vishweshwar, P.; Weyna, D. R.; Zaworotko, M. J. Polymorphs, Salts, and Cocrystals: What's in a Name? Cryst. Growth Des. 2012, 12, 21472152.

(11) Aitipamula, S.; Vangala, V. R.; Chow, P. S.; Tan, R. B. H. Cocrystal Hydrate of an Antifungal Drug, Griseofulvin, with Promising Physicochemical Properties. Cryst. Growth Des. 2012, 12, 5858-5863.

(12) Yan, Y.; Chen, J. M.; Geng, N.; Lu, T. B. Improving the Solubility of Agomelatine via Cocrystals. Cryst. Growth Des. 2012, 12, 2226-2233.

(13) Mannava, M. K. C.; Suresh, K.; Nangia, A. Enhanced Bioavailability in the Oxalate Salt of the Anti-Tuberculosis Drug Ethionamide. Cryst. Growth Des. 2016, 16, 1591-1598.

(14) Clarke, H. D.; Hickey, M. B.; Moulton, B.; Perman, J. A.; Peterson, M. L.; Wojtas, Ł.; Almarsson, Ö.; Zaworotko, M. J. Crystal Engineering of Isostructural Quaternary Multicomponent Crystal Forms of Olanzapine. Cryst. Growth Des. 2012, 12, 4194-4201.

(15) Thakuria, R.; Nangia, A. Olanzapinium Salts, Isostructural Solvates, and Their Physicochemical Properties. Cryst. Growth Des. 2013, 13, 3672-3680.

(16) Karanam, M.; Dev, S.; Choudhury, A. R. New Polymorphs of Fluconazole: Results from Cocrystallization Experiments. Cryst. Growth Des. 2012, 12, 240-252.

(17) Karanam, M.; Choudhury, A. R. Structural Landscape of Pure Enrofloxacin and Its Novel Salts: Enhanced Solubility for Better Pharmaceutical Applicability. Cryst. Growth Des. 2013, 13, 1626-1637.

(18) Cohen, B. M.; Harris, P. Q.; Altesman, R. I.; Cole, J. O. Amoxapine: Neuroleptic as Well as Antidepressant? Am. J. Psychiatry 1982, 139, 1165-1167.

(19) Ban, T. A. Amoxapine and Viloxazine: Review of the Literature with Special Reference to Clinical Studies. Psychopharmacol. Bull. 1979, 15, 22-25.

(20) Lydiard, R. B.; Gelenberg, A. J. Amoxapine-An Antidepressant With Some Neuroleptic Properties?: A Review of Its Chemistry, Animal Pharmacology and Toxicology, Human Pharmacology, and Clinical Efficacy. Pharmacotherapy 1981, 1, 163-178.

(21) Stewart, D.; Stavness, C.; King, G.; Antle, B.; Law, M. A critical appraisal of amoxapine. Phys. Occup. Ther. Pediatr. 2006, 26, 5-24.

(22) Lydiard, R. B.; Gelenberg, A. J. Amoxapine - An Antidepressant With Some Neuroleptic Properties?: A Review of Its Chemistry, Animal Pharmacology and Toxicology, Human Pharmacology, and Clinical Efficacy. Pharmacotherapy 1981, 1, 163-178.

(23) Kinney, J. L.; Evans, R. L. J. Evaluation of Amoxapine. Clin. Pharmacol. 1982, 1, 417-424.

(24) Wander, T. J.; Nelson, A.; Haruo, O.; Richelson, E. Antagonism by Antidepressants of Serotonin S1 and S2 Receptors of Normal Human Brain in Vitro. Eur. J. Pharmacol. 1986, 132, 115-121.

(25) Richelson, E.; Nelson, A. Antagonism by Antidepressants of Neurotransmitter Receptors of Normal Human Brain in Vitro. J. Pharmacol. Exp. Ther. 1984, 230, 94-102.

(26) Graveleau, C.; Paust, H.-J.; Schmidt-grimminger, D.; Mukhopadhyay, A. K. Presence of a 5-HT7Receptor Positively Coupled to Adenylate Cyclase Activation in Human Granulosa-Lutein Cells1. J. Clin. Endocrinol. Metab. 2009, 85, 1277-1286.

(27) Apiquian, R.; Fresan, A.; Ulloa, R. E.; De La Fuente-Sandoval, C.; Herrera-Estrella, M.; Vazquez, A.; Nicolini, H.; Kapur, S. Amoxapine as an Atypical Antipsychotic: A Comparative Study vs Risperidone. Neuropsychopharmacology 2005, 30, 2236-2244.

(28) Calvo, M. B.; Garcia, M. J.; Pedraz, J. L.; Dominguez-Gil, A. Bioavailability of Amoxapine in Experimental Animals. Boll. Chim. Farm. 1986, 125, 307-311.

(29) Tamblyn, K. C.; Conner, D. E. Bactericidal Activity of Organic Acids against Salmonella Typhimurium Attached to Broiler Chicken Skin. J. Food Prot. 1997, 60, 629-633. 
(30) Aakeröy, C. B.; Fasulo, M. E.; Desper, J. Cocrystal or Salt: Does It Really Matter? Mol. Pharmaceutics 2007, 4, 317-322.

(31) Sarma, B.; Nath, N. K.; Bhogala, B. R.; Nangia, A. Synthon Competition and Cooperation in Molecular Salts of Hydroxybenzoic Acids and Aminopyridines. Cryst. Growth Des. 2009, 9, 1546-1557.

(32) Cruz-Cabeza, A. J. Acid-base Crystalline Complexes and the $\mathrm{p} K_{\mathrm{a}}$ Rule. CrystEngComm 2012, 14, 6362.

(33) Marvin 5.10.1, 2017. http://www.chemaxon.com (accessed Nov 20, 2017).

(34) Tetko, I. V.; Gasteiger, J.; Todeschini, R.; Mauri, A.; Livingstone, D.; Ertl, P.; Palyulin, V. A.; Radchenko, E. V.; Zefirov, N. S.; Makarenko, A. S.; et al. Virtual Computational Chemistry Laboratory - Design and Description. J. Comput.-Aided Mol. Des. 2005, 19, 453-463.

(35) Joshi, M.; Kumar, P.; Kumar, R.; Sharma, G.; Singh, B.; Katare, O. P.; Raza, K. Aminated Carbon-Based "cargo Vehicles" for Improved Delivery of Methotrexate to Breast Cancer Cells. Mater. Sci. Eng., C 2017, 75, 1376-1388.

(36) Higuchi, T. K.; Connors, K. A. Phase Solubility Techniques. Adv. Anal. Chem. Instrum. 1965, 4, 117-212.

(37) Dolomanov, O. V.; Bourhis, L. J.; Gildea, R. J.; Howard, J. A. K.; Puschmann, H. IUCr. OLEX2: A Complete Structure Solution, Refinement and Analysis Program. J. Appl. Crystallogr. 2009, 42, 339341.

(38) Sheldrick, G. M. IUCr. Crystal Structure Refinement with SHELXL. Acta Crystallogr., Sect. C: Struct. Chem. 2015, 71, 3-8.

(39) Sheldrick, G. M. IUCr. A Short History of SHELX. Acta Crystallogr., Sect. A: Found. Crystallogr. 2008, 64, 112-122.

(40) Macrae, C. F.; Bruno, I. J.; Chisholm, J. A.; Edgington, P. R.; McCabe, P.; Pidcock, E.; Rodriguez-Monge, L.; Taylor, R.; van de Streek, J.; Wood, P. A.; et al. Mercury CSD 2.0 - New Features for the Visualization and Investigation of Crystal Structures. J. Appl. Crystallogr. 2008, 41, 466-470. 